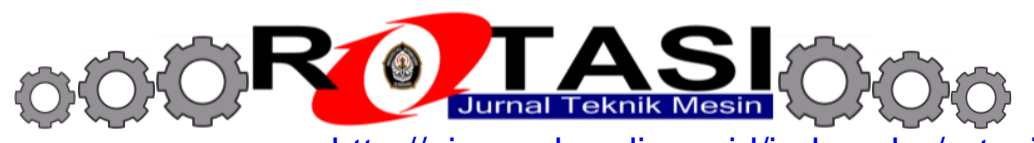

Available online at Website http://ejournal.undip.ac.id/index.php/rotasi

\title{
MEKANISME PERPINDAHAN BATANG PADA VARIASI PARAMETER DESAIN FEEDER CELAH BERPUTAR
}

\author{
*Susilo Adi Widyanto, Atanasius Priharyoto Bayuseno \\ Jurusan Teknik Mesin, Fakultas Teknik, Universitas Diponegoro \\ J1. Prof. Sudharto,Tembalang, Semarang 50275, Indonesia \\ *Email: susilo70@yahoo.com
}

\begin{abstract}
Abstrak
Permintaan ekspor produk poru yang relatif besar yaitu sekitar 500 ribu per tahun mutlak membutuhkan sistem produksi terotomasi. Penelitian ini bertujuan untuk merancang bangun mekanisme feeder mesin pengecat otomatis produk poru. Penelitian dilakukan secara eksperimental dengan menguji model mekanisme feeder sehingga diperoleh kinerja terbaik yang dinyatakan dalam kekontinyuan pengumpanan dan minimalnya gangguan pengoperasian akibat dis-orientasi benda kerja saat pengumpanan. Penelitian diawali dengan studi literatur untuk memperoleh informasi-informasi desain feeder yang telah diaplikasikan. Pemilihan mekanisme dilakukan yang dilanjutkan dengan proses desain dan fabrikasi model. Pengujian pengoperasian mekanisme feeder dilakukan untuk memperoleh kondisi yang optimal. Parameter pengoperasian divariasikan, yang meliputi: sudut bidang pemuatan $\left(20,30\right.$ dan $\left.40^{\circ}\right)$, kecepatan mekanisme pemuatan (11, 22 dan $\left.33 \mathrm{rpm}\right)$, massa dan kekasaran permukaan batang serta kondisi susunan batang pada bidang pemuatan. Hasil pengujian menunjukkan bahwa peningkatan sudut bidang pemuatan dan putaran mekanisme pengumpan menunjukkan dampak yang serupa yaitu mendorong batang bergerak menjauhi bidang pemuatan searah putaran mekanisme pemuatan. Massa batang berkonstribusi positif terhadap derajat keberhasilan pemuatan, sedangkan kehalusan permukaan batang berkontribusi negatif pada derajat keberhasilan pemuatan. Susunan batang bertumpuk menyebabkan ketidakstabilan posisi batang yang berdampak negatif pada derajat keberhasilan pemuatan.
\end{abstract}

Kata kunci : feeder, batang kayu, slot pengumpan, bidang pemuatan, mekanisme pemuatan.

\section{PENDAHULUAN}

Salah satu produk ekspor yang dilakukan oleh IKM lokal untuk pasar Jepang adalah produk poru. Berdasarkan bentuknya, poru berupa batang kayu berdiameter $30 \mathrm{~mm}$ dengan panjang $2000 \mathrm{~mm}$ (Gambar 1). Toleransi kelengkungan harus di bawah $5 \mathrm{~mm}$. Target produksi per bulan mencapai 500.000 batang per tahun sehingga diperlukan proses produksi terotomasi.

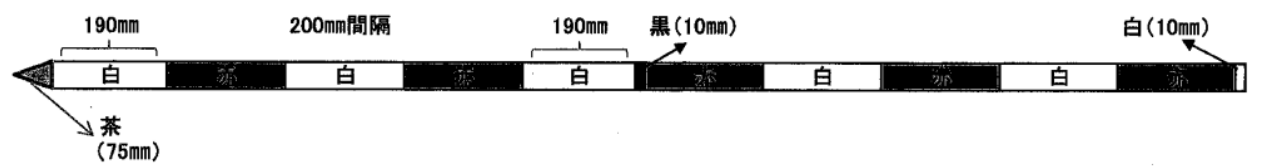

Gambar 1. Produk poru.

Poru dibuat dengan proses dowel untuk menghasilkan bentuk poros dari bentuk berpenampang kotak. Dengan proses pendempulan, seluruh pori kayu ditutup yang dilanjutkan dengan proses pengamplasan. Selanjutnya batang poru dicat dasar putih dengan proses ekstrusi. Tahap akhir pengecatan tongkat dilakukan dengan pemberian konfigurasi warna merah dengan menggunakan mesin pengecat otomatis yang akan dikembangkan. Dari Gambar 1 terlihat bahwa setiap tongkat terdapat 5 bagian warna merah. Bila pengecatan warna merah tersebut dilakukan secara manual, maka selain membutuhkan waktu yang sangat lama, kondisi batas cat yang baik sulit diperoleh bila pengecatan dilakukan dengan penyemprotan. Mempertimbangkan hal tersebut, maka rancang bangun mesin pengecatan konfigurasi warna merah penting dilakukan untuk meningkatkan produktivitas.

Salah satu bagian penting dari mesin produksi adalah mekanisme feeder yang digunakan untuk proses pemuatan bahan baku ke dalam siklus kerja mesin. Berbagai mekanisme feeder telah dikembangkan, tetapi pemilihan yang tepat yang diikuti proses modifikasi sangat penting dilakukan untuk disesuaikan dengan karakteristik bahan baku yang digunakan. Penelitian ini secara khusus ditujukan untuk merancang bangun mekanisme feeder mesin pengecat otomatis produk poru yang terbuat dengan bahan kayu dengan panjang benda kerja sekitar 2 meter. Variasi parameter yang mucul pada bahan baku poru antara lain berupa kelurusan, diamater, kondisi permukaan dan berat yang ditentukan oleh jenis kayunya. 
Penerapan mesin produksi terotomasi terutama didasarkan pada usaha untuk meningkatkan kualitas dan produktivitas, oleh karena itu pelibatan komponen produksi yang tidak stabil harus ditekan seminimal mungkin. Unsur manusia dilibatkan bila tahapan atau siklus yang dilakukan bersifat kompleks atau diperlukan penanganan secara khusus. Demikian halnya dalam proses loading (pemuatan) bahan baku ke dalam mesin produksi, prosedur pemuatan harus dapat dilakukan semudah mungkin sehingga mekanisme yang digunakan harus mampu melakukan pengaturan yang diperlukan secara mandiri.

Salah satu mekanisme pemuatan bahan baku ke dalam mesin yang telah lama digunakan adalah hoper yang pada awalnya digunakan untuk bahan baku butiran (granular). Bebrapa peneliti telah melakukan studi terhadap pola aliran serbuk dalam hoper, diantaranya Jenike pada tahun 1964 menurunkan sebuah persamaan, metode pengukuran dan sifat material serbuk. Nguyen dkk. [1] meneliti kemampuan alir serbuk yang disebabkan oleh gravitasi dalam hoper. Mereka menggunakan criteria empiris yang telah digunakan oleh Jenike dan Johanson [2,3]. Salah satu informasi penting dari penelitian Nguyen adalah sudut batas massa alir suatu hopper untuk material serbuk pasir adalah $20^{\circ}$, sedangkan untuk bahan glas adalah $25^{\circ}$.

Bila material yang diatur alirannya berupa batang, korelasi empiris aliran material jauh berbeda dibandingkan serbuk. Untuk menentukan kondisi aliran material dalam hoper, beberapa hal yang berhubungan dengan ukuran dan bentuk material dapat dinyatakan: massa per unit material, kondisi permukaan, bentuk benda kerja yang menyangkut titik kontak antar unit material maupun parameter-parameter geometri hoper. Oleh karena itu untuk pengaturan aliran material dengan geometeri khusus diperlukan beberapa modifikasi hoper antara lain dengan menambahkan mekanisme jebakan berputar atau sumber getaran untuk mengantisipasi terjadinya surface locking diantara benda kerjanya. Berbagai bentuk feeder benda-benda silindris yang mengacu pada mekanisme hoper seperti ditunjukkan dalam Gambar 2, Gambar 3, Gambar 4, Gambar 5 dan Gambar 6 .

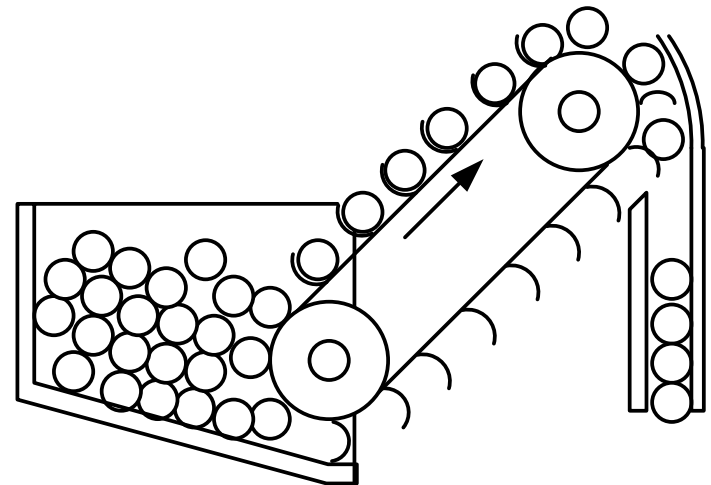

(a)

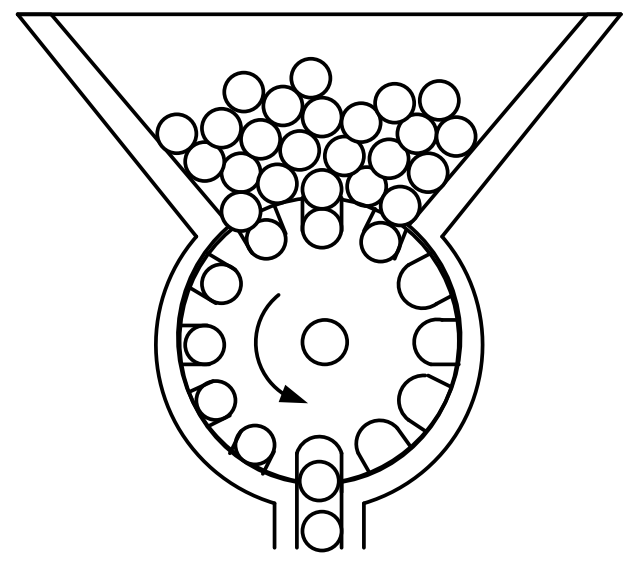

(b)

Gambar 2. (a) benda kerja poros yang diletakkan dalam hoper, dengan memanfaatkan mekanisme konveyor satu per satu benda kerja diumpankan ke dalam mesin produksi, (b) Benda kerja poros dimasukkan ke dalam hoper, dengan menggunakan mekanisme penjebak berputar satu per satu benda kerja diumpankan ke dalam mesin produksi [4]

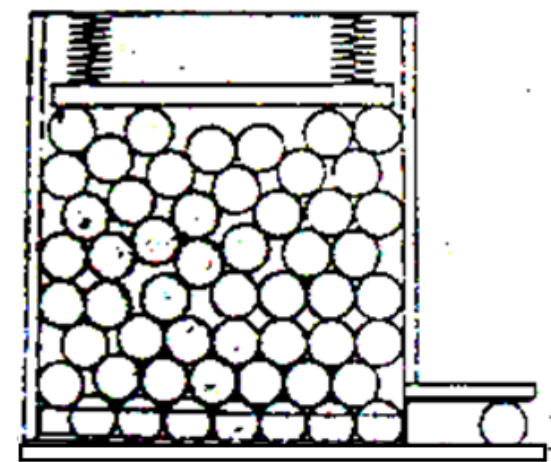

Gambar 3. Benda kerja poros dimasukkan ke dalam hoper, dengan memanfaatkan vektor gaya penekanan yang bertitik tangkap pada bidang kontak antar permukaan benda kerja, satu per satu benda kerja keluar diumpankan ke dalam mesin produksi [4] 


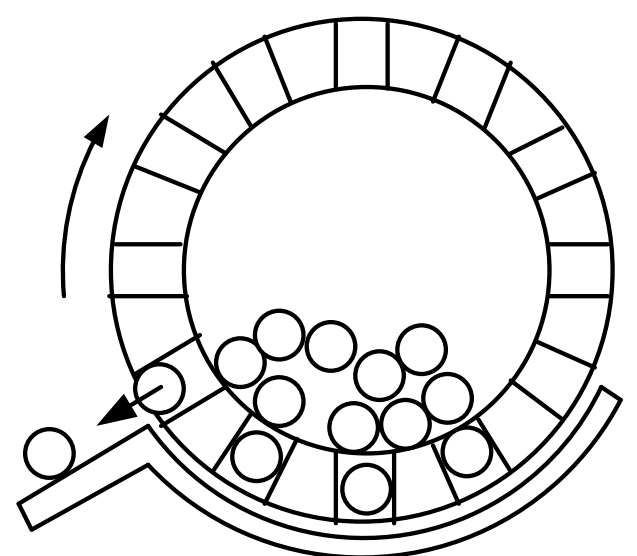

Gambar 4. Benda kerja poros dimasukkan ke dalam drum yang sisi luarnya terdapat jebakan untuk mengarahkan benda kerja keluar drum satu per satu [4]

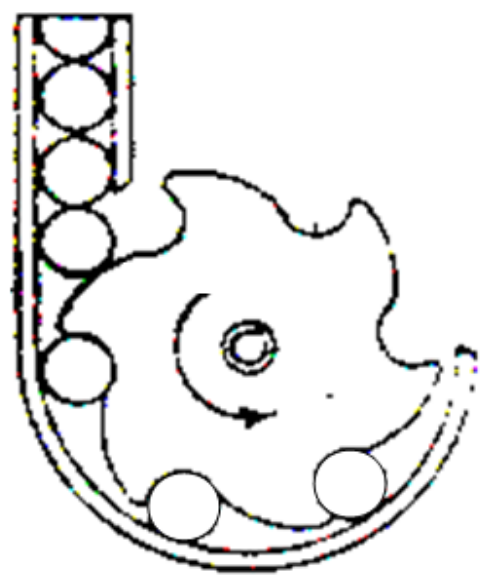

Gambar 5. Benda kerja poros dimasukkan ke dalam antrian dan diumpankan ke dalam mesin dengan menggunakan mekanisme penjebak berputar [4]

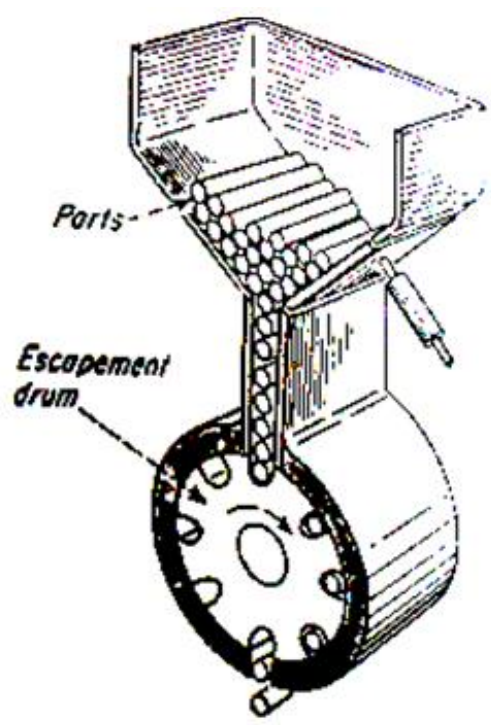

Gambar 6. Benda kerja poros dimasukkan ke dalam hopper yang digetarkan sehingga satu per satu masuk ke dalam antrian untuk diumpankan ke dalam mesin produksi [4]

\section{METODOLOGI PENELITIAN}

Penelitian ini secara khusus ditujukan untuk menentukan parameter-parameter yang berpengaruh pada derajat kerberhasilan pemuatan batang pada mekanisme hoper sebagai perangkat feeder mesin terotomasi. Berdasarkan konstruksi yang pernah dikembangkan sebelumnya, konstruksi hopper yang diteliti merupakan salah satu dari 
konstruksi-konstruksi yang dibahas di atas (Gambar 2b). Untuk mencapai tujuan yang ditentukan, penelitian ini dilaksanakan dengan metode sebagai berikut:

\subsection{Model Konstruksi Hopper yang Diteliti}

Penelitian ini membahas pola aliran material yang berupa batang pada konstruksi hopper yang digunakan sebagai material loading pada suatu mesin produksi poru. Konstruksi hopper seperti ditunjukkan dalam Gambar 7. dengan konstruksi tersebut, posisi hopper dapat diatur sudut masuknya. Dengan mengatur putaran mekanisme loading, perilaku batang untuk mencapai lubang pemuatan diamati.

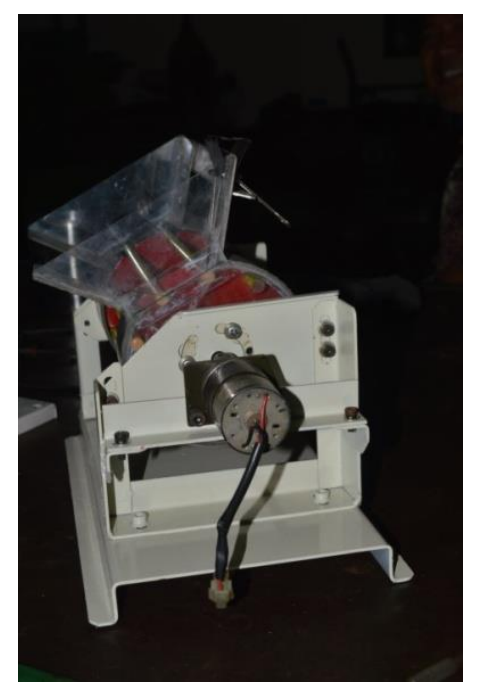

Gambar 7. Konstruksi hopper yang digunakan dalam penelitian.

\subsection{Parameter Penelitian}

Secara umum penelitian ini dilakukan untuk menentukan putaran optimum mekanisme pemuatan untuk berbagai jenis batang sehingga keberhasilan pemuatan mencapai kondisi yang maksimum. Faktor pemosisian batang dalam hopper dan pola gerakan yang terjadi juga diamati sehingga dapat ditentukan pemosisian batang yang terbaik. Secara detail parameter-parameter penelitian diuraikan sebagai berikut:

a. Sudut bidang masuk hopper : dalam aplikasinya riilnya batang-bantang benda kerja dimasukkan kedalam hopper dengan cara menata di atas bidang masuk hoper. Sudut kemiringan bidang masuk menentukan besarnya gaya gravitasi yang mendorong batang masuk ke dalam slot pengumpan. Variasi sudut bidang masuk meliputi: 20, 30 dan 40 derajat. Penentuan variasi sudut bidang masuk seperti ditunjukkan dalam Gambar 8.

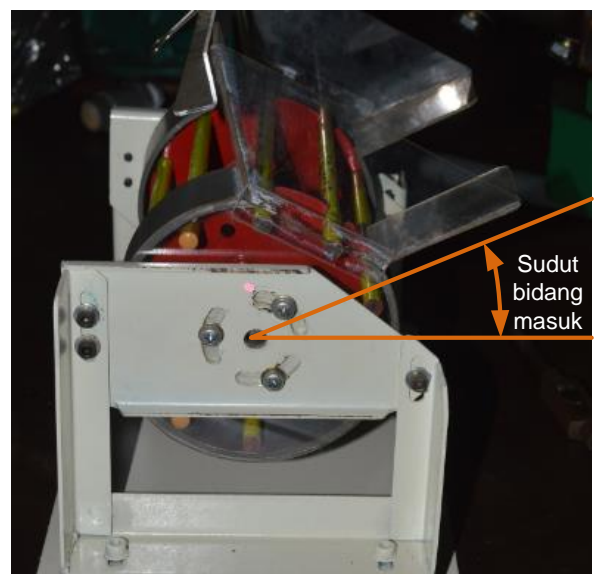

Gambar 8. Parameter sudut bidang pemuatan.

b. Putaran sistem pengumpan: putaran sistem pengumpan menentukan kecepatan produksi mesin yang disuplai oleh sistem hoper. Namun bila putaran sistem pengumpan terlalu cepat, maka akan berdampak pada mekanisme masuknya batang ke dalam sistem slot pengumpan. Untuk itu putaran optimal sistem pengumpan perlu ditentukan. Dalam penelitian ini variasi putaran sistem pengumpan meliputi: $11 \mathrm{rpm}, 22 \mathrm{rpm}$ dan $33 \mathrm{rpm}$. Pengaturan putaran mekanisme pemuatan dengan menggunakan power suply variabel tegangan dan pengukuran putarannya menggunakan infra red tachometer seperti ditunjukkan dalam Gambar 9. 


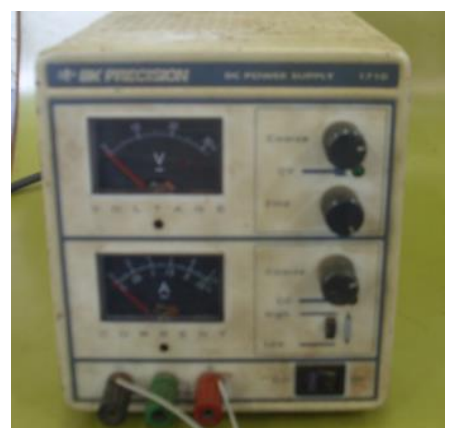

(a)

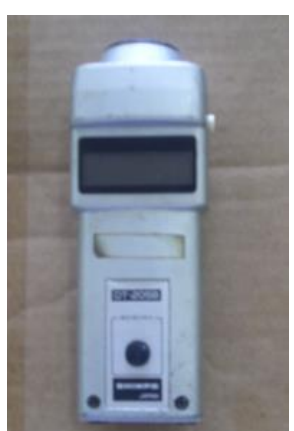

(b)

Gambar 9. (a) Power suply dengan variabel tegangan, (b) Infrared tachometer.

c. Jenis batang yang digunakan meliputi: dua jenis batang kayu, batang pipa aluminium dan batang baja dimana semua jenis batang berdiamater $8 \mathrm{~mm}$. Hasil pengukuran massa tiap jenis batang dinyatakan dalam Tabel 1 .

Tabel 1. Jenis Batang Yang Digunakan Dalam Pengujian Kinerja Feeder Dan Hasil Pengukuran Massanya

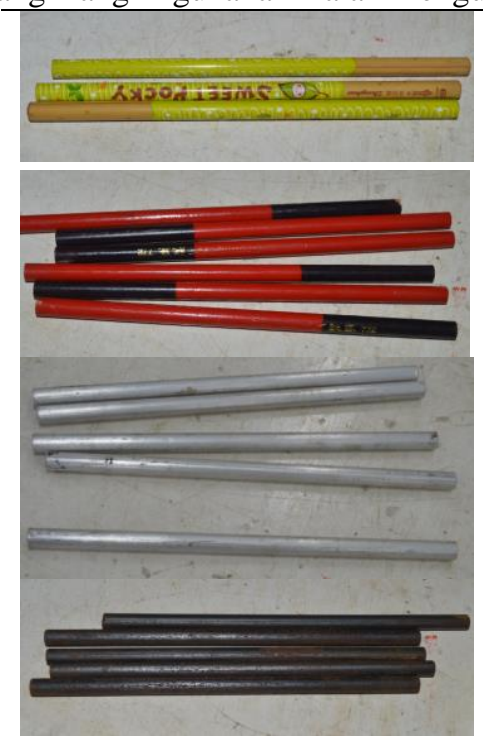

$\begin{array}{ll}\text { Batang kayu 1 } & 5,259 \\ & 5,87 \\ & 6,45 \\ & 6,106 \\ & 5,57 \\ \text { Batang kayu 2 } & 5,3 \\ & 5,7 \\ & 5,35 \\ & 4,77 \\ & 5,8 \\ & 7,4 \\ \text { Batang } & 7,4 \\ \text { aluminium } & 7,36 \\ & 7,36 \\ & \\ \text { Bantang baja } & 61,87 \\ & 61,528 \\ & 61,408 \\ & 61,193 \\ & 61,88\end{array}$

d. Kondisi tumpukan. Formasi batang yang diletakkan pada bidang pemuatan divariasikan, yaitu tanpa tumpukan dan dengan tumpukan seperti ditunjukkan dalam Gambar 10.

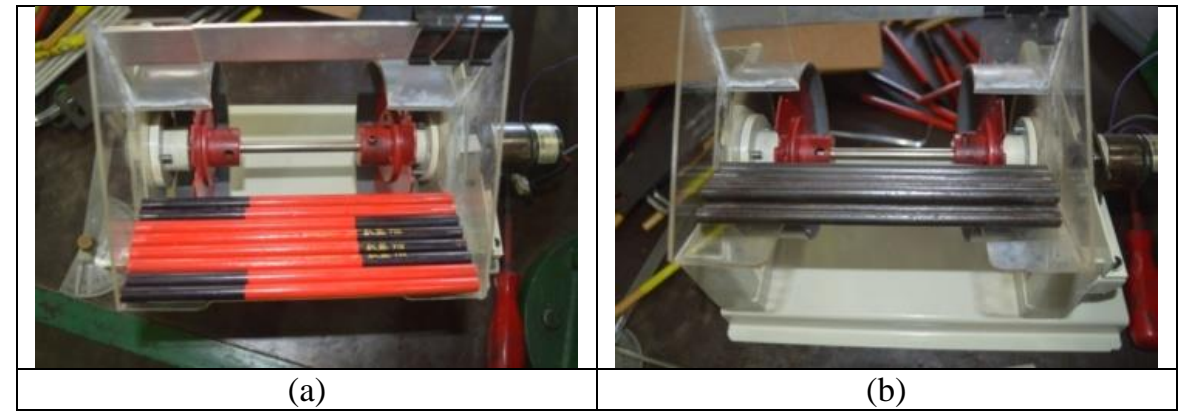

Gambar 10. Susunan batang pada bidang pemuatan: (a) Batang tanpa tumpukan, (b) Batang bertumpuk.

\section{HASIL PENELITIAN}

\subsection{Pengaruh Putaran Mekanisme Pemuatan pada Derajat Keberhasilan Pemuatan}

Derajat keberhasilan pemuatan hopper dipengaruhi oleh kecepatan putar mekanisme pemuatan seperti ditunjukkan dalam Gambar 11. Derajat keberhasilan pemuatan menurun dengan peningkatan kecepatan putaran mekanisme pemuatan. Peningkatan kecepatan mekanisme pemuatan menyebabkan peningkatan ketidakstabilan posisi batang (terutama batang dengan massa yang kecil) dan semakin singkatnya kesempatan batang masuk ke dalam lubang pemuatan. Ketidak-stabilan posisi meningkatkan peluang masuknya salah satu ujung ke slot pemuatan yang menyebabkan mekanisme gagal beroperasi. Hal tersebut terlihat dari kecenderungan ketidakteraturan orientasi batang, 
dimana semakin cepat putaran, semakin acak orientasi batang yang menyebabkan kegagalan mekanisme beroperasi. Dari hasil observasi visual yang dilakukan, peningkatan kecepatan putar mekanisme pemuatan menyebabkan batang semakian jauh bergerak ke arah depan meninggalkan lokasi pemuatan pada ujung bidang miring.

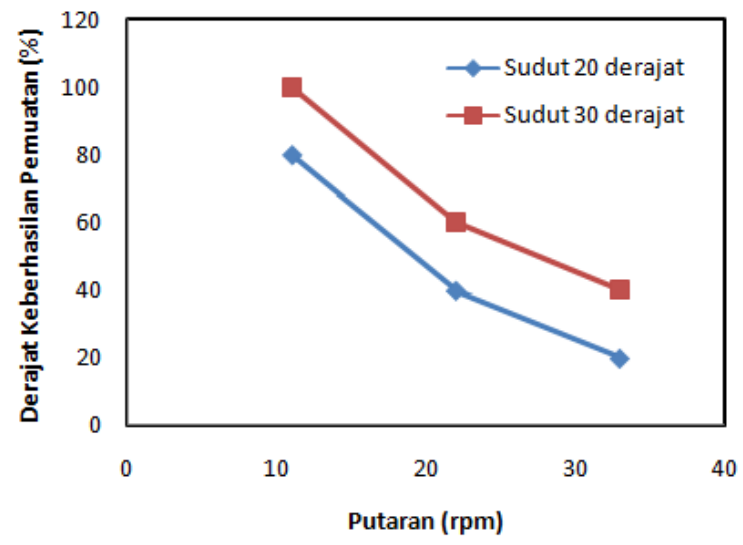

Gambar 11. Pengaruh putaran terhadap derajat keberhasilan pemuatan (susunan batang tanpa tumpukan).

\subsection{Pengaruh Massa dan Kondisi Kehalusan Permukaan Batang pada Derajat Keberhasilan Pemuatan}

Keberhasilan pemuatan batang oleh konstruksi hoper dipengaruhi oleh massa dan kondisi kehalusan permukaan batang seperti ditunjukkan dalam Gambar 12. Batang C (aluminium dengan massa 7,4 g) pada putaran $22 \mathrm{rpm}$ dengan sudut masuk $20^{\circ}$ gagal memasuki celah pemuatan, sedangkan batang yang kasar, batang D berbahan baja, keberhasilan pemuatan mencapai kondisi tertinggi yaitu $80 \%$. Kondisi ini menunjukkan bahwa kekasaran permukaan batang secara dominan berpengaruh pada keberhasilan pemuatan hoper.

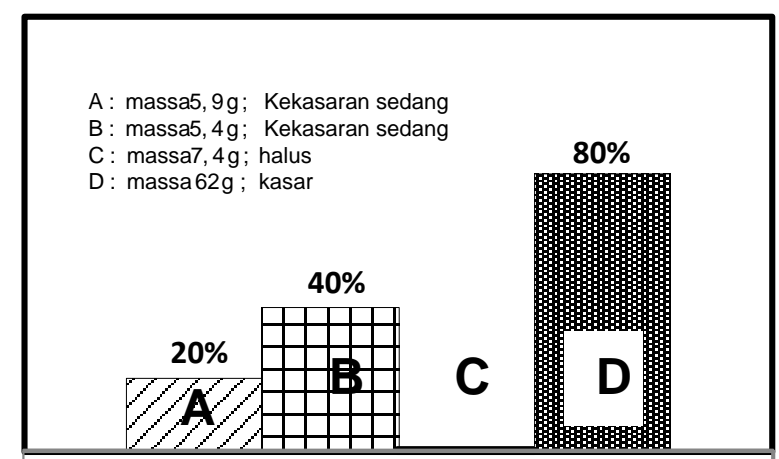

Gambar 12. Pengaruh jenis bahan pada derajat keberhasilan pemuatan (sudut bidang pemuatan $20^{\circ}$, putaran $22 \mathrm{rpm}$ ).

Ketidak -rataan permukaan batang D secara dominan berupa garis sejajar batang. Kondisi ini menyebabkan bentuk kegagalan pemuatan (kegagalan pengoperasian hoper) sebagian besar berupa terjepitnya batang antara bidang vertikal dengan sisa celah pemuatan seperti ditunjukkan dalam Gambar 13.

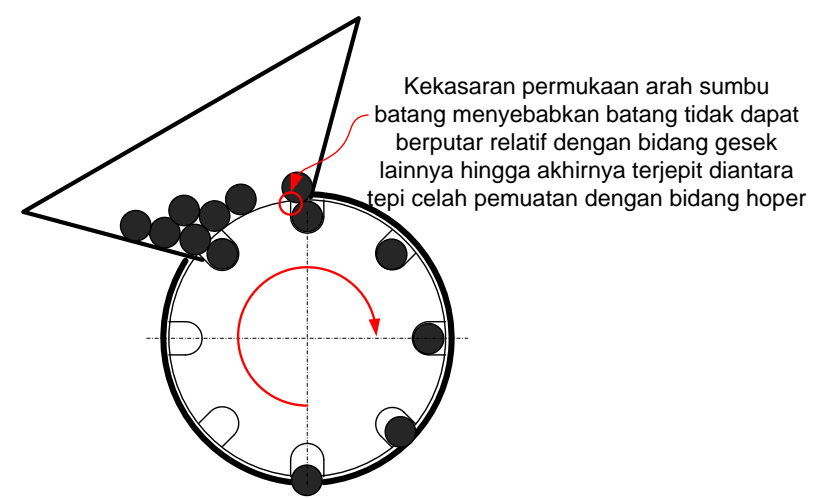

Gambar 13. Kondisi hoper gagal beroperasi akibat kekasaran permukaan arah sejajar sumbu batang.

Untuk menentukan pengaruh massa dan kehaluasan permukaan batang pada derajat keberhasilan pemuatan secara rinci, masing-masing faktor diamati pengaruhnya dengan penjelasan sebagai berikut: ketika batang berada di 
lokasi pemuatan, gerakan relatif antar batang maupun batang dengan bidang pemuatan dipengaruhi oleh kondisi kekasaran permukaan. Pengaruh kekasaran permukaan pada derajat keberhasilan pemuatan ditunjukkan dalam Gambar 14. Pada permukaan halus pengendalian posisi relatif antara permukaan mekanisme pemuat dengan batang sulit dilakukan akibat rendahnya koefisien gesek antara dua permukaan tersebut, sehingga formasi kesejajaran gerakan batang sulit dipertahankan. Kondisi tersebut meningkatkan peluang masuknya salah satu ujung batang pada celah pemuatan yang menyebabkankan mekanisme gagal beroperasi. Pada sisi lain kekasaran permukaan menyebabkan batang sulit melepaskan diri dari celah sisa pemuatan seperti ditunjukkan pada fenomena Gambar 13.

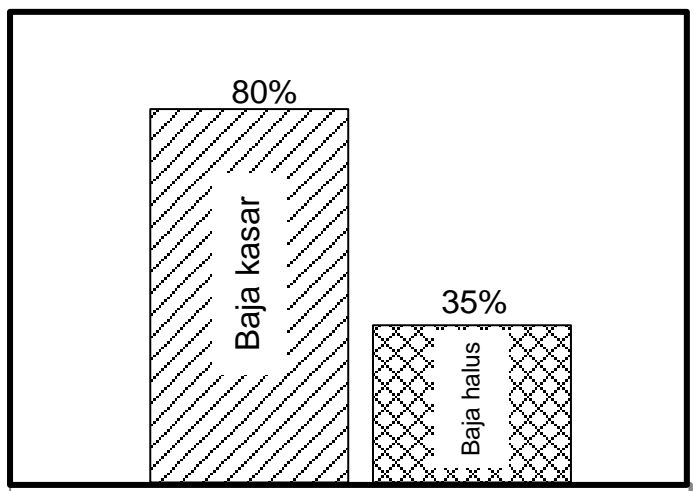

Gambar 14. Pengaruh kekasaran permukaan pada derajat keberhasilan pemuatan (bahan batang baja, massa 61 gram, sudut bidang muat $20^{\circ}$, putaran $33 \mathrm{rpm}$ ).

Dari hasil pengujian dengan variasi massa batang diperoleh bahwa peningkatan massa batang berdampak pada peningkatan derajat keberhasilan pemuatan. Kestabilan posisi batang pada saat berada pada lokasi pemuatan dipengaruhi oleh massa batang. Celah pemuatan menstimulasi perubahan posisi batang, dimana semakin cepat putaran mekanisme pemuatan dampak ketidakstabilan bantang semakin besar. Kestabilan posisi batang ditentukan oleh massanya dan faktor tersebut berperan dalam penentuan tingkat keberhasilkan masuknya batang ke celah pemuatan. Korelasi massa batang dan derajat keberhasilan pemuatan batang aluminium maupun baja seperti ditunjukkan dalam diagram bantang Gambar 15 .

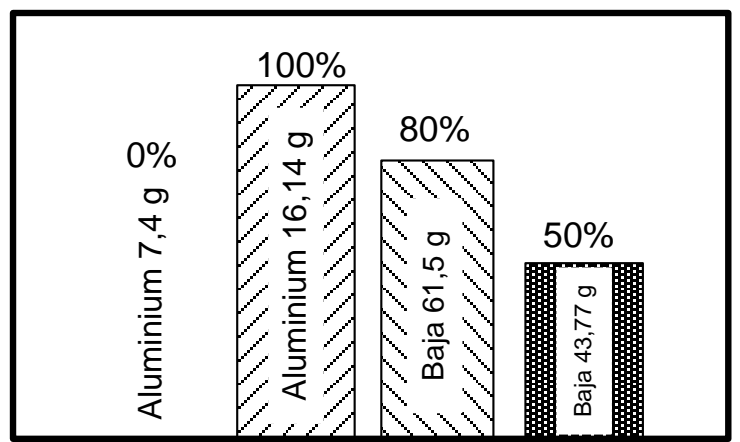

Gambar 15. Pengaruh massa batang pada derajat keberhasilan pemuatan untuk batang aluminium dan baja.

Dari penjelasan di atas terlihat bahwa derajat keberhasilan pemuatan batang secara dominan dipengaruhi oleh massa batang dibandingkan kondisi kehaluasan permukaannya. Peningkatan massa batang berkontribusi positif terhadap derajat keberhasilan pemuatan, tetapi sebaliknya kehalusan permukaan berkontribusi megatif terhadap derajat keberhasilan pemuatan.

\subsection{Pengaruh Sudut Bidang Pemuatan pada Derajat Keberhasilan Pemuatan}

Peningkatan sudut bidang masuk secara efektif diterapkan pada pengoperasian putaran rendah mekanisme pemuatan. Gambar 16. menunjukkan bahwa pada putaran $11 \mathrm{rpm}$, peningkatan sudut bidang berdampak pada peningkatan derajat keberhasilan pemuatan batang, sedangkan pada putaran $33 \mathrm{rpm}$ derajat keberhasilan pemuatan relatif rendah sehingga tidak disarankan. Dari Gambar 16 tersebut juga memperlihatkan bahwa pengaruh putaran terhadap derajat keberhasilan pemuatan lebih dominan dibandingkan perubahan sudut bidang masuk. Dilihat dari kondisi gagalnya hoper beroperasi, pada putaran yang semakin tinggi, tingkat keacakan yang dihasilkan juga semakin tinggi. Bantang tumpang tindih ketika memasuki celah pemuatan yang menyebabkan hoper langsung terhenti. Kondisi kegagalan pemuatan seperti ditunjukkan dalam Gambar 17. 


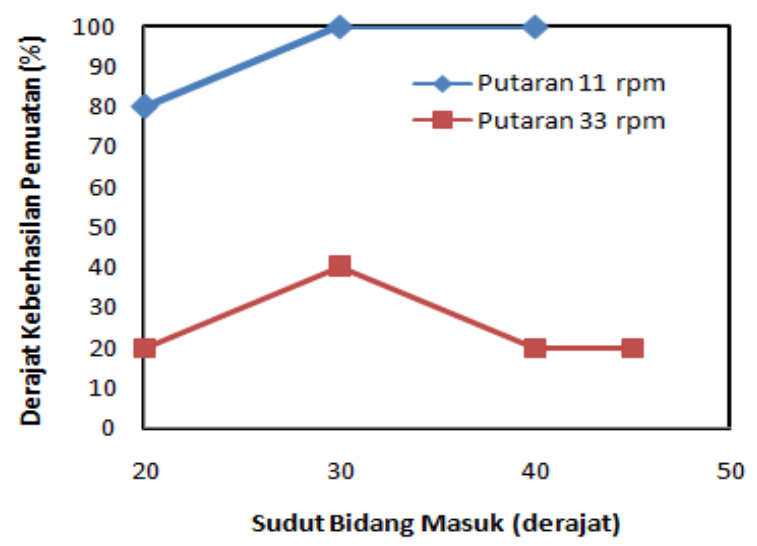

Gambar 16. Pengaruh sudut bidang masuk pada derajat keberhasil pemuatan.

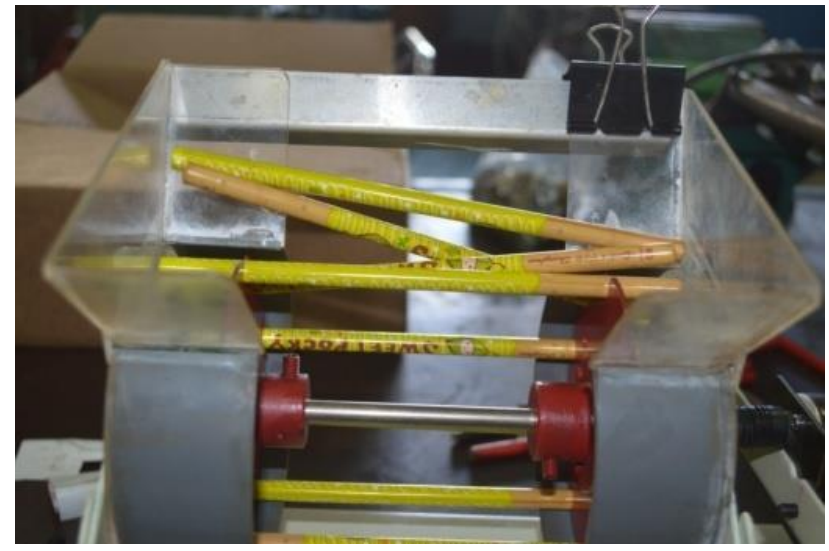

Gambar 17. Kondisi kegagalan pemuatan, batang tumpang tindih sehingga menghentikan putaran mekanisme pemuatan.

\subsection{Pengaruh Susunan Batang pada Derajat Keberhasilan Pemuatan}

Kondisi tumpukan batang pada bidang pemuatan juga berpengaruh pada derajat keberhasilan pemuatan terutama pada sudut bidang masuk 20 derajat (Gambar 18). Kondisi tumpukan menyebabkan keacakan formasi batang pada lokasi pemuatan. Gerakan mekanisme pemuatan lebih berpengaruh pada tumpukan batang atas sehingga mempermudah gerakan batang searah putaran mekanisme penggerak. Kondisi keacakan susunan batang yang berada di atas mekanisme pemuatan menyebabkan potensi terjebaknya salah satu ujung ke dalam slot pemuatan meningkat. Hal tersebut ditunjukkan oleh kondisi tumpukan batang akhir yang menyebabkan gagalnya hoper beroperasi yang cenderung lebih acak pada kondisi susunan batang bertumpuk. Kondisi susunan batang yang menyebabkan hoper gagal beroperasi akibat susunan batang bertumpuk seperti ditunjukkan dalam Gambar 19.

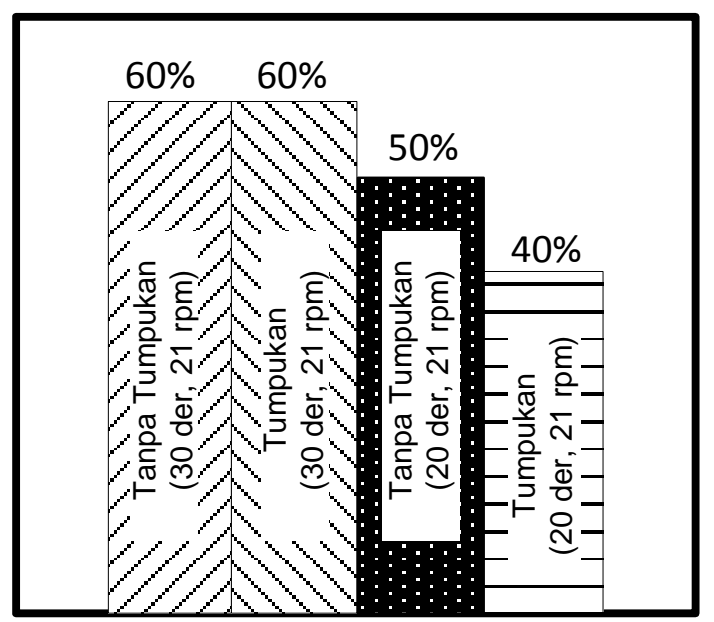

Gambar 18. Pengaruh susunan batang pada bidang pemuatan terhadap derajat keberhasilan pemuatan (batang A). 


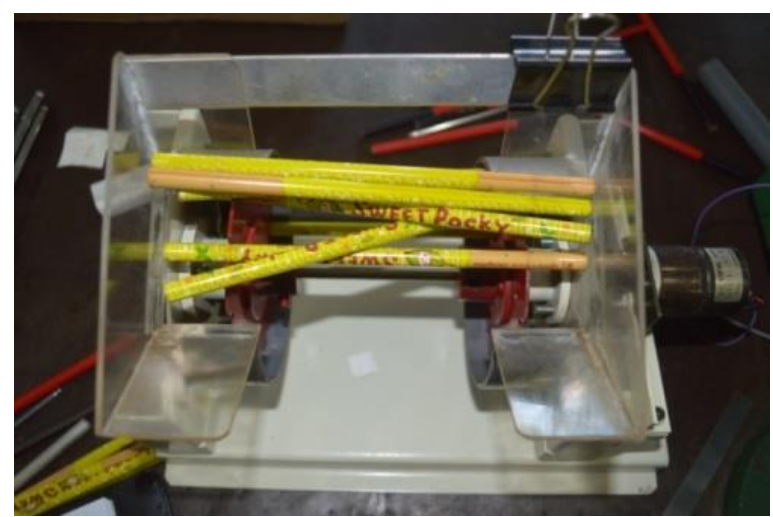

Gambar 19. Kondisi tumpang tindih batang yang menyebabkan kegagalan pengoperasian hoper.

\section{KESIMPULAN}

a. Dampak yang dihasilkan dari peningkatan sudut bidang pemuatan dan putaran menunjukkan kecenderungan yang sama, yaitu mendorong batang bergerak ke depan mengikuti arah putaran mekanisme pemuatan.

b. Sudut bidang pemuatan yang kecil menyebabkan turunnya peluang batang dapat memasuki celah pemuatan dengan sempurna. Kondisi tersebut ditunjukkan pada pengaturan sudut bidang pemuatan sebesar 20 derajat tidak semua celah terisi, sedangkan pada sudut 30 dan 40 derajat, semua celah pemuatan terisi sempurna.

c. Kontribusi massa batang pada derajat keberhasilan pemuatan lebih besar dibandingkan kondisi kehaluasan permukaan batang. Semakin besar masaa batang, semkain besar derajat keberhasilan pemuatan kondisi sebaliknya terjadi untuk tingkat kehalusan permukaan batang.

d. Kondisi tumpukan batang berpengaruh pada derajat keberhasilan pemuatan terutama untuk sudut bidang pemuatan yang rendah $\left(20^{\circ}\right)$. Semakin jauh posisi batang dari permukaan bidang pemuatan, semakin besar pengaruh putaran mekanisme pemuatan pada bergeraknya batang sesuai arah putarannya.

\section{DAFTAR PUSTAKA}

[1] Nguyen, T.V., Brennen, C. and Sabersky, R.H. (1979), "Gravity Flow of Granular Materials in Conical Hoppers", Journal of Applied Mechanics.

[2] Jenike, A.W. and Johanson, J.R. (1968), "Bin Loads", Journal of the Structural Division, Proceeding of the ASCE, Vol. 94, pp.1011.

[3] Jenike, A.W. (1964), "Storage and Flow Solids," Bulletin No. 123 Utah Engineering Experiment Station, University of Utah, Salt Lake City, Utah,

[4] Chironis, N.P. (1978), "Machine Devices and Instrumen-tation”, McGraw-Hill Book Company, New York 